\title{
FABRICATION AND MECHANISM OF PASSENGER ALIGHTING FROM MOVING TRAIN WITHOUT STOPPING TRAIN
}

\author{
Sagar H. T ${ }^{1}$, Raghu $S^{2}$, Rajeshkumar D. $V^{3}$, Rakshith H. $\mathbf{N}^{4}$, Ramachandra $\mathrm{V}^{\mathbf{5}}$ \\ ${ }^{1}$ Assistant professor, Rajeev institute of Technology, Hassan, Karnataka, India \\ ${ }^{2} U G$ Student, Department of Mechanical Engineering, Rajeev Institute of Technology, Hassan, Karnataka, India \\ ${ }^{3} U G$ Student, Department of Mechanical Engineering, Rajeev Institute of Technology, Hassan, Karnataka, India \\ ${ }^{4} U G$ Student, Department of Mechanical Engineering, Rajeev Institute of Technology, Hassan, Karnataka, India \\ ${ }^{5} U G$ Student, Department of Mechanical Engineering, Rajeev Institute of Technology, Hassan, Karnataka, India
}

\begin{abstract}
Normally the train stopping at small station where very few people want to get down or alight the train, we will be losing lot of fuel and time of rest of the passengers who do not alight, we propose to device some mechanism by which the train is slowing down and not stopping at the small stations where people can get down from train without train stopping by which we are saving fuel for slowing down the momentum and starting it up from zero to pick up that momentum and also saving lot of time of other passenger who do not get down. Here we are making pallet arrangement and railing on the train connecting from first bogie to last bogie of the train which becomes the part of the train and a pallet will be moving from first bogie to last bogie in reverse direction. When alighting point arrives, the people who want to get down in that platform have to stand on the pallet and at arrow mark of the platform, the pallet will start moving back in the same speed as the train is traversing ahead, by which the momentum with respect to the platform will be zero during which the people can get down from pallet to platform and who want to alight can step up the pallet and so when the pallet reaches the last bogie, the pallet movement stops and it continues to move with the train and the people who are on the pallet will get into the train now.
\end{abstract}

Throughout the world today, railway systems are being expected to play important transport roles and to develop further. To do so they must be punctual provide high-density service and be in harmony with the environment. Roughly 160 million persons ride in trains each day around the world. Two main reasons account for the high utilization rate for trains, safety and punctuality.

Keywords: Pallet, Gear, DC motor, Sprocket, Track.

\section{INTRODUCTION}

One of the systems in the world of transportation is Railways, which carries heavy loads next to shipping. The loads may be in the form of passengers or cargo. Railway becomes a biggest public transportation. Railways are always opting for passenger convenient systems and are developing various comforts and are devising easy operation for safety. The importance of inter-module rail operations within the global supply chain has never been more apparent. Leveraging the tracking technology solutions implemented by Indian railways, shipping companies and other industries and general public have recently begun to utilize Indian railways and rely on it more than earlier.

Indian railways are the state owned railway network of India. The ministry of railways is responsible for the operation, maintenance and growth of the rail network in India, the fifth largest network in the world in terms of track length, behind the US, Russia, Canada and China. Indian railways is one of the largest and busiest rail network in the world, transporting eighteen million passengers daily and more than two million tons of freight daily.

The railways traverse the length and breadth of the country; the routes cover a total length of more than
63,327 kilometers. As of 2008, IR owned about 225,000 wagons, 45,000 coaches and 8300 locomotives and ran more than 18,000 trains daily, including about 8,984 passenger trains and 9,387 goods trains .

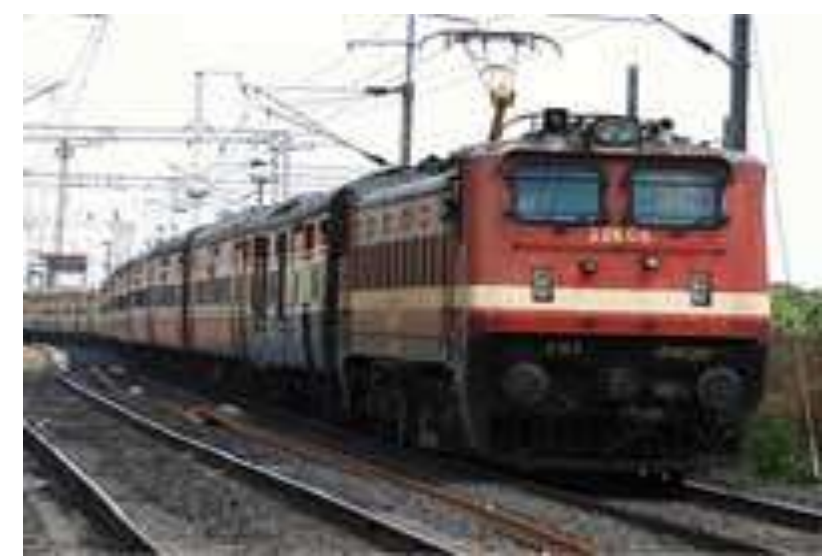

Fig 1 Indian Train

Railways were first introduced to India in 1853. By 1947, the year of India's independence, there were forty-two rail systems. In 1951 the systems were nationalized as one unit, becoming one of the largest networks in the world. IR operates both long distance and suburban rail systems. 
Indian railways operates about 9000 passenger trains and transports 17 million passengers daily across twenty-eight states and three union territories. The passenger division is the most preferred form of long distance transport in most of the country. A standard passenger train consists of eighteen coaches but some popular trains can have unto 24 coaches. Coaches are designed to accommodate anywhere from 18 to 72 passengers, but during the holiday seasons or when on busy routes, more passengers may travel in a coach. Most regular trains have coaches connected through vestibules.

\section{PROBLEM STATEMENT}

Trains are carrying huge load of passengers and luggage, utilizing too much fuel and energy for transporting. The energy spent by the train to start up from the station and to stop at stations draws maximum fuel rather than to reach from a place to other. At some remote stations where in very few or a single person wants to alight or delight, the entire train has to come to a halt which is very expensive.

To curtail this problem we propose to have a system in the train in which the train will slow down at the station and a pallet mechanism is moving on a chain mechanism carrying the person wants to delight from the door, who can get down from the train onto the platform. The pallet mechanism is gear driven from the axle of the bogie rotating in the reverse direction in the same speed of the bogie axle. This makes the pallet to be moving backwards towards the train movement and relative with the platform, it seems to be stationery which is convenient for the passenger to step up and down.

\section{OBJECTIVE}

- To design and fabricate a track on which a engine is moving the bogie.

- $\quad$ To design and make the train assembly with frame in which a drive mechanism being powered by DC motor, wheels, for front and rear to rotate to have the movement of the train assembly on the track.

- To design and fabricate the pallet mechanism which drives the pallet in the reverse direction when the train is moving in the forward direction at the particular speed. To design and fabricate the pallet mechanism engaging motorized when desired.

\section{WORKING PRINCIPLE}

In this we are providing an engine with motor, gearbox, axle, wheels and bearing and bearing housing and DC batteries for the drive. The engine can be started by putting the button on. The engine is attached by a bogie (in this model we are making only one bogie of long length instead of many bogies which is linked between each other) and the chain is fixed from first door to the last door of the last bogie, and on this chain is the pallet mechanism which starts moving back due to the rotation in reverse direction relative to the train direction. The track is made on which the engines along with the bogies are moving. The bogies which is having axles and bearings and bearing housing rotates and the chain starts moving at the button pressing and makes a pallet to move backwards in the same speed of the forward motion. The passengers can stand on this pallet which moves backward, and relative with the platform it is stationery and passengers can safely alight or delight. The pallet movement can be stopped by the button activation.

\section{CAlCulation}

VELOCITY $=$ Displacement $/$ Time Taken

Where, In Indian Trains,

Displacement (Platform), D $=250 \mathrm{~m}$

Velocity $\quad, \mathrm{V}=20 \mathrm{~km} / \mathrm{hr}=5.55 \mathrm{~m} / \mathrm{s}$

Time Taken, $\mathrm{t}=\mathrm{D} / \mathrm{V}$

$=250 / 5.55$

$=45.4 \mathrm{sec}$

For 5-8 Passengers,

5 passengers,

$\mathrm{t}=9 \mathrm{sec} /$ passenger

8 passengers,

$\mathrm{t}=5.8 \mathrm{sec} /$ passenger

If we increase the pallet, the alight and delight will more.

\section{PARTS REQUIRED}

1. Base frame

2. Motor holder

3. Wheels

4. Battery box

5. Spur gears

6. Mild steel plugs for gears

7. Ball bearing housing

8. Ball bearings

9. Wheel axles

10. Chain engaging axle

11. Guide for pallet

12. Chain sprocket

13. Chain sprocket bushes

14. Pivot bush

15. Pivot axle.

16. Circuit holder

17. Limit switch holder

18. Limit switch hitter

19. Limit switch holder base

20. Track

21. Pallet

22. Intermediate link

23. Pull up link

24. Motor crank

25. Pivot drag plate

\section{BASIC METHOD OF ACHIEVING THE} SPEED OF THE PALLET MOVEMENT IN

\section{REVERSE TO, WITH RESPECT TO THE SPEED OF THE TRAIN MOVEMENT}

We have used a DC motor to engage the driven gear which is sliding on the sprocket axle which drives the chain. One drive gear is fixed on the wheel axle. When the bogie is pulled by the engine, the wheels are rotating and the drive 
gear mounted on this axle will rotate. When the alighting place is reached, by button pressing the DC motor will engage the driven gear on the sprocket axle sliding it to match the drive gear thereby rotating the sprocket axle which drives the chain in the opposite direction. The pallet is made and the pin is projecting out at the base which engages the slot of the chain and the pallet moves back on the guide railing driven by the chain and it will stop at the end by the closing of the micro-switch. The wheel and sprocket diameter are made of the same diameter due to which the circumference of the wheels and the sprocket are same which makes the rotation of the sprocket axle and the wheel to be same which makes the pallet movement relative to the drive wheel will remain the same. The gears used are of same number of teeth for the drive and the driven so the speed remains the same.

\section{ENERGY STORAGE SYSTEMS}

The largest, most effective and useful energy storage system is seawater, which in different forms provides energy when required. However, talking about manmade storage systems, flywheel is a very useful method of storing energy. However, the amount of energy stored is very small yet it is of sufficient use in vehicles, factories, etc. Another very useful form of energy storage is the battery system. Battery stores chemical energy in the form of reactive species (during charging) and releases energy as electrical power (during discharging).

\section{BATTERY SYSTEMS}

A battery constitutes of cells. The basic components of an electrolyte cell are a positive and negative electrode and an electrolyte. Usually positive electrode is oxide or sulphide etc, while the negative electrode is metal. The electrolyte acts as an internal circuit between the electrodes. The electrolyte is a non-conductor for electrons to avoid selfdischarge. Other components of a cell include current collectors and separators. Of the two types of batteries available viz, primary batteries and secondary batteries, we consider the secondary batteries, as they can be recharged while the primary batteries are for single discharge and single use.

\section{ADVANTAGES}

Train fuel is saved to the great extent.

- The fuel spent to propel the train from zero to the particular speed takes time and consumes lot of fuel almost 6 times of fuel than the normal drive.

- Train traveling time is saved, saving in many man hours, which accounts to crores of hours of the total passengers time is counted.

- National saving, in cost and manpower.

- Passengers can safely and confidently travel.

- No manual monitoring, it is controlled automatically.

- No human mistakes occur since it is done by control circuit avoiding the mistakes.

- Simple in design.

- Less maintenance.

\section{DISADVANTAGES}

- Mechanism is to be maintained properly.

- It is to be still developed for practical usage which needs lot of research.

- This is a model to show the basic working principle.

\section{CONCLUSION}

One of the systems in the world of transportation is Railways, which carries heavy loads next to shipping. The loads may be in the form of passengers or luggage's. Railway becomes a biggest public transportation. Railways are always opting for passenger convenient systems and are developing various comforts and are devising easy operation for safety. The consumption of fuel during starting up or stopping at the small station is more.

So we proposed to have a pallet mechanism where the platform is stationary, during which movement of pallet is backward and the train moving ahead, during which the passengers can alight or delight from the pallet to the platform.

\section{FUTURE DEVELOPMENT}

This concept can be given a thought and research and development can be done in that direction to overcome the problem of relative motion and balance of the person on the moving pallet.

The conceptual working demonstration is is successful to show the working of the pallet seems to be stationery with respect to the platform during the pallet moving back and the train moving ahead during which the passengers can alight or de-alight from the pallet to the platform.

\section{ACKNOWLEDGEMENT}

I express immense gratitude to my guide Mr. SAGAR H. T., Assistant Professor and Mr. Sunil S. G., Assistant Professor, Department of Mechanical Engineering, RIT, Hassan for having extended his priceless technical expertise. I also thank him for his patient thoughtful guidance and also for his most generous support and encouragement towards the development of the Project work.

\section{REFERENCES}

[1] Zhang Qi, Han Baom, Li Dewei, "Modeling and Simulation of Passenger alighting and Boarding Movement in Beijing Metro Stations", $22^{\text {nd }}$ Science Direct, PP No. 12-18, $17^{\text {th }}$ May 2016.

[2] Dewei Li, Winnie Daamen, Rob M. P Goverdan, "Estimation of train dwell time at short stops based on track occupation event data", $6^{\text {th }}$ international Conference on Railway Operations Modeling and Analysis, Rail Tokyo, PP No. 1- 6, 2015.

[3] Joshua K Anderson, Sudhir Gota, Hao Wan, "Journal of Public Transportation", National Center for Transit Research, Vol.-17, 2014 
[4] Agostino N., Umberto C., Luca R, “A schedule-based assignment model with explicit capacity constraints for congested transit network", transportation Research Part C, 2012.

[5] Ming Yao, Phag Zhao and Ke Qiao, "Simulation of urban rail transmit network based on multi agent approach", Journal of Industrial Engineering and Management, PP No. 1-13, 2012.

[6] Jyu Cherng Jong, En Fu Chang, "Investigation and Estimation of Train Dwell Time for Timetable Planning", WCRR Lille 2011, $9^{\text {th }}$ World Congress Railway Research, PP No. 1-5, 2011.

[7] Ling H., Xu, "Calculation Method of Emergency Passenger Flow in Urban Rail Network", Journal of Tingyi University (Natural Science), 2011.

[8] Xu R.H., Luo Q., \& Gao P., "Passenger Flow Distribution Model and Algorithm for Urban Rail Transit Network Based on Multi-route Choice", Journal of The China Railway Society, 2009.

[9] Si B.F., Mao B.H., \& Liu Z.L., "Passenger Flow Assignment Model and Algorithm for Urban Railway Traffic Network under the Condition of Seamless Transfer", Journal of the China Railway Society, 2007.

[10] Shang L., \& Lu H.P., "Urban Microscopic Traffic Simulation System and Its Application", Journal of System Simulation, 2006.

\section{BIOGRAPHIES}

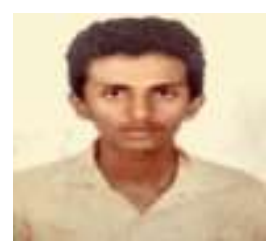

Raghu S, UG Student, Department of Mechanical Engineering, Rajeev Institute of Technology, Hassan, Karnataka ,India

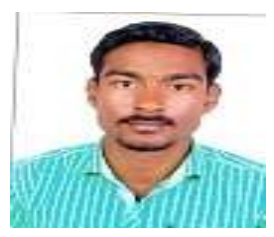

Rajeshkumar D. V, UG Student, Department of Mechanical Engineering, Rajeev Institute of Technology, Hassan, Karnataka ,India

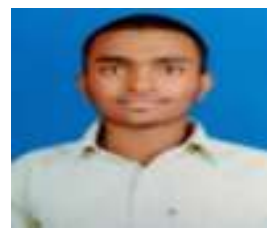

Rakshith H N, UG Student, Department of Mechanical Engineering, Rajeev Institute of Technology, Hassan, Karnataka ,India

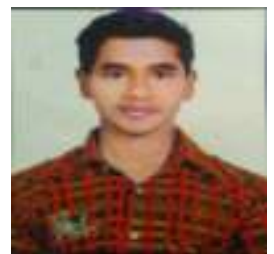

Ramachandra V, UG Student, Department of Mechanical engineering, Rajeev Institute of Technology, Hassan, Karnataka ,India 